УДК 372.881 .161 .1

http://doi.org/10.36906/KSP-2020/38

Супронова А.H.

Военная академия материально-технического обеспечения им. генерала армии А.В. Хрулёва г. Санкт-Петербург, Россия

\title{
ФАКТОРЫ УСПЕШНОГО ПРОФЕССИОНАЛЬНО ОРИЕНТИРОВАННОГО ОБУЧЕНИЯ РУССКОМУ ЯЗЫКУ ИНОСТРАННЫХ ВОЕННОСЛУЖАЩИХ
}

Аннотация. В статье актуализируется учет профессиональной доминанты в преподавании дисциплин гуманитарного цикла, в частности, русского языка как иностранного в аспекте военного образования. Рассматриваются факторы, активизирующие интерес к изучению языка специальности и влияющие на успешное формирование профессионально ориентированной коммуникативной компетенции иностранных военнослужащих.

Ключевые слова: гуманитарные дисциплины; русский язык как иностранный; военное образование; профессионально ориентированное обучение; язык специальности.

В контексте современной образовательной парадигмы проблемы гуманитарных дисциплин входят в число одних из наиболее актуальных. Исследователи акцентируют внимание на инновационных тенденциях, потребностях современности, цифровизации образовательной среды и других факторах, обусловливающих определенные подходы к преподаванию данных дисциплин.

Вопросы, связанные с особенностями преподавания гуманитарных дисциплин в вузе, рассматриваются в работах Е.О. Аквазбы и П.С. Медведева [1], О.И. Алексеенко и Т.В. Даниленко [2], Г.М. Васильевой и О.В. Ротмистровой [3; 8], С.К. Матисова и С.С. Худалея [5], Э.Н. Платоновой и И.И. Садовой [6], А.В. Раппопорта [7], Ю.Б. Шагбановой [10] и др., где подчеркивается эффективность анализируемых дисциплин при условии учета профессиональной доминанты. В таком контексте неизбежен вопрос о том, каким образом могут быть сопряжены профессиональная составляющая, характерная для дисциплин в рамках будущей специальности студента, и дисциплины гуманитарного цикла, роль которых, как справедливо замечают С.К. Матисов и С.С. Худалей, недооценивается обучающимися. Такие дисциплины воспринимаются как неактуальные, невостребованные относительно будущей специальности, хотя являются «непременным условием современного, разностороннего университетского образования, которое призвано готовить <..> творчески мыслящих, всесторонне развитых и культурных людей» [5, с. 316]. Представляется, что такого противоречия можно избежать, если, во-первых, расставить приоритеты в сторону вектора междисциплинарной интеграции, которая «с позиций формирования компетенций <..> становится логическим основанием саморазвития 
будущего специалиста» [11, с. 47], во-вторых, акцентировать внимание на ценности знаний, которые дают гуманитарные дисциплины молодому специалисту в условиях тенденций развития современного общества. В контексте этих рассуждений актуальна точка зрения Э.Н. Платоновой и И.И. Садовой, утверждающих следующее: чтобы «научить будущих специалистов ставить и решать задачи в определенной предметной области», «студенты должны не только изучить профессиональную предметную область, но и овладеть приемами и методами анализа проблемы, постановки и решения задач. Все это определяет профессиональный потенциал специалиста и его творческие возможности изобретательно подходить к решению различных проблем» [6, с. 146].

Рассматривая особенности преподавания гуманитарных дисциплин в контексте междисциплинарности, О.И. Алексеенко и Т.В. Даниленко подчеркивают актуальность формирования «базовой основы гуманитарного знания в контексте профессионального образования в современных условиях, максимальный учет специфики учебных предметов», что будет положительно влиять на повышение учебной мотивации обучающихся. Кроме того, «живой» язык дисциплин гуманитарного цикла «оказывает прямое воздействие на психологические аспекты обучения студентов, закладывающих перспективы дальнейшего самообучения и самосовершенствования», а «творческий характер педагогического процесса, умело включающий инновации при необходимом сохранении традиций преподавания, делает гуманитарные дисциплины особым интерактивным полем учебной деятельности, отвечающим перспективным тенденциям инноватизации» [2, с. 6]. А.В. Раппопорт подчеркивает важную роль гуманитарных дисциплин, во-первых, во взаимосвязи с дисциплинами общественных и естественных наук, во-вторых, в обогащении этих дисциплин «гуманитарным духом». Ввиду этого «задача всех современных учебных заведений должна состоять в том, чтобы и естественные, и гуманитарные дисциплины были направлены на формирование и развитие гуманистической личности, потому как гуманитарную культуру можно считать неким фундаментом духовной культуры учащихся» [7]. На существенный воспитательный потенциал гуманитарных дисциплин обращают внимание Е.О. Аквазба и П.С. Медведев [1]. Положительную ценностную доминанту гуманитарных дисциплин в контексте профессионально ориентированного обучения подчеркивает Ю.Б. Шагбанова: «Студенты, а также выпускники высшего учебного заведения не должны утрачивать гражданские позиции, уважение к окружающей действительности, к истории и традициям страны и своего народа, понимание важности экологической, корпоративной культуры и т. п. Поэтому возрастает роль преподавания гуманитарных дисциплин, которые нацелены на формирование мировоззрения студента не просто как будущего профессионала, а как “гражданина” своей фирмы, предприятия, организации любого уровня и разных отраслей хозяйственной жизни» [10].

Гуманитарные дисциплины чрезвычайно значимы и в системе военного образования, что актуализируется в рамках данной работы. В частности, нами акцентируется внимание на иноязычном образовании, причем особая роль в данном аспекте отводится обучению русскому языку как иностранному. Это связано, во-первых, с тем, что процесс преподавания данной дисциплины направлен на формирование у иностранных студентов коммуникативной компетенции, а в рамках будущей специальности - профессионально ориентированной коммуникативной компетенции, связанной с овладением обучающимися языком для специальных целей. Во-вторых, принципиально подчеркнуть потенциал 
иноязычного образования, которое, как известно, представляет собой органичное сочетание четырех аспектов - познавательного, развивающего, воспитательного и учебного. В рамках первого обучающиеся познают одновременно и иностранную культуру, и язык как компонент данной культуры. Второй из перечисленных аспектов предусматривает развитие различных способностей обучающихся и речемыслительных механизмов. Третий ориентирован на воспитание нравственных качеств личности. В рамках четвертого аспекта во главу угла ставятся задачи по формированию у обучающихся различных видов речевой деятельности, т. е. умений говорить, читать, писать на иностранном языке. Примечательно, что «идея культуры пронизывает все четыре процессуальных аспекта, каждый из которых органично входит в целостный образовательный процесс» [4, с. 143].

Заметим, что традиционно при обучении языку специальности культуроориентированная составляющая, которая характерна для иноязычного образования, не учитывается. Приоритетна, как правило, узкопрофессиональная направленность. Безусловно, овладение языком будущей специальности - важнейшая задача в профессионально ориентированном обучении РКИ, однако без выхода за эти узкопрофессиональные рамки невозможно усиление учебно-познавательной мотивации иностранных обучающихся. Особенно этот фактор значим в сфере военного образования: принципы военной дидактики ориентированы на ценностный аспект образовательного пространства, на его гармонизацию и гуманизацию. Процесс обучения и воспитания в данном случае подразумевает синтез интеллектуальной, нравственной, учебнопрофессиональной, эстетической и других составляющих, что всегда учитывается при обучении иностранных курсантов общему владению русским языком. Однако и в курсе профессиональной направленности данной дисциплины нельзя забывать о том, что ценностная доминанта будущей военной специальности обучающихся должна пронизывать каждую тему урока.

Такой подход можно реализовать, если взять за основу ранее предложенный нами принцип, который заключается в следующем: «от узкопрофессионального понимания языковых элементов до их чувственного восприятия» [9, с. 206]. С целью реализации этого принципа «специальные языковые элементы нужно рассматривать в совокупности с маркерами военной культуры» [9, с. 207], т. е. на фоне концептуального поля военной картины мира и национальной картины мира. Следовательно, в учебный процесс включаются концепты, образы и другие феномены, концентрирующие «в себе актуальный материал для формирования культурообусловленных компетенций» [3, с. 26]. О.В. Ротмистрова подчеркивает эффективность работы с подобным материалом, считая принципиальным вопрос о том, «зачем этот материал нужен обучающимся, какую пользу они могут извлечь из данного материала, как он связан с будущей профессией, какова его ценность в рамках межкультурного общения и т. д.» [8, с. 95].

В военном вузе в рамках любой темы по русскому языку как иностранному ключевым является образ военнослужащего, поскольку:

1) качества военнослужащего позиционируются в аспекте военной педагогики и военной психологии;

2) маркеры военной культуры - доблесть, честь, достоинство, верность воинской присяге, патриотизм, героизм, отвага, мужество и др. - отражены в воинских уставах и других военных документах; 
3) перечисленные маркеры репрезентируют образ военнослужащего в русской концептосфере, в значимых текстах культуры и медиапространстве;

4) образ русского солдата является сквозным в художественной литературе, песенном творчестве и др.

Приведем небольшой фрагмент позиционирования данного образа в рамках темы «Военная логистика», предусматривающей презентацию лексики по языку специальности «Тыловое обеспечение»:

1. На первом этапе вводится специальная лексика: используется прием кластеризации, т. е. соответствующие наименования сгруппированы по семантическим признакам и представлены в кластерах «Военные автомобили», «Военные грузоперевозки» и др. Так, например, в кластер «Военные автомобили» входят наименования как современных автомобилей, так и использовавшихся во время Первой мировой войны и Великой Отечественной войны. Например: 1) грузовой автомобиль «ГАЗ-АА», или легендарная «полуторка» (название в соответствии с грузоподъемностью), которая была незаменима в годы Великой Отечественной войны; «ЗИС-5», или «трехтонка»; американский грузовой автомобиль «Studebaker US6» («Cтудебекер»/«Cтудебеккер», поступивший на вооружение по программе так называемого ленд-лиза), на котором в годы Великой Отечественной войны перевозили реактивные установки «Катюша» и др.; 2) современные автомобили: бронированные автомобили «Тайфун-К» $и$ «Тайфун-У», легкобронированный бронеавтомобиль КамАЗ-43269 «Выстрел», специальный бронированный автомобиль «Булат», грузовой автомобиль повышенной проходимости «Урал-4320», модульный бронированный автомобиль «Волк» и др.

2. Второй этап предусматривает активизацию данной лексики на материале микротекстов. При этом важно акцентировать внимание обучающихся на вопросах и заданиях, развивающих критическое мышление, призывающих к рассуждению и дискуссии, например: «Проанализируйте названия автомобилей. Связаны ли, по ватему мнению, эти названия с техническими характеристиками автомобилей? Аргументируйте ответ», «Какое значение имеют грузоперевозки в мирное и военное время?», «Расскажите о роли военных автомобилей в период Великой Отечественной войны (например, во время блокады Ленинграда)», «В чем вы видите значимость военной логистики в мирное и военное время?» (вопрос актуален при активизации лексики обоих кластеров: «Военные автомобили» и «Военные грузоперевозки») и т. п.

3. На третьем этапе целесообразна активизация специальной лексики на материалах СМИ, рекламных текстах, фрагментах документальных, художественных, анимационных фильмов, произведений изобразительного искусства, в рамках работы с которыми можно предложить вопросы и задания, предусматривающие характеристику героев, оценку их поступков и т. п. Например: «Можно ли назвать военных шоферов героями? Почему?», «Соответствуют ли действия героев положениям воинских уставов?», «Есть ли место подвигу в настоящее время? Приведите примеры», «Проанализируйте современную рекламу военной техники. Какие слова используются для ее характеристики? Может ли такая реклама повлиять на выбор будущей военной специальности? Почему?», "Проанализируйте агитационные плакаты Великой Отечественной войны. Как вы понимаете их смысл? Можно ли сказать, что такие плакаты обладали огромной силой воздействия? Аргументируйте свою точку зрения», «На основании сюжета фильма/фрагмента текста 
расскажите о роли автомобилей в военной истории России», «Как вы думаете, почему в России есть монументы/стель/памятники воинам-автомобилистам?» и т. п. Этот этап важен в плане повышения мотивации обучающихся, поскольку делается акцент на образе военнослужащего в национальной картине мира, на значимости профессии военнослужащего, на воинских ценностях, традициях и ритуалах, в целом на функциях армии как социального института государства. В качестве средств обучения привлекаются различные источники и данные разных областей знания: материалы из воинских уставов, истории (особенно актуальна военная история), культурологии, географии, военной тактики и др.

Отметим также, что на каждом этапе важно включать задания в контексте межкультурной коммуникации, когда в процессе сопоставления тех или иных феноменов происходит пересечение разных культур - русской и родной культуры военнослужащих (ср.: «Какие военнье автомобили состоят на вооружении в армии вамей странь?», «Расскажите о роли военных автомобилей/военных грузоперевозок в вашей стране» и др.). Как известно, учет родной культуры обучающихся является существенным мотивирующим фактором при изучении иностранного языка.

Исходя из вышеизложенного, очевидными факторами, влияющими на успешное профессионально ориентированное обучение русскому языку как иностранному в условиях военного вуза, мы считаем:

1. учет аспектов военной дидактики;

2. повышение учебно-профессиональной мотивации обучающихся с помощью материалов, позволяющих акцентировать внимание на ценностных аспектах будущей специальности;

3. включение в учебный процесс фрагментов из воинских уставов и документов, военных медиатекстов, военной рекламы, художественных текстов, военной публицистики и др. материалов, отражающих ценностную картину мира военнослужащего;

4. активизацию элементов языка специальности на фоне концептуального поля военной картины мира и национальной картины мира;

5. учет родной культуры обучающихся;

6. реализацию принципа «от узкопрофессионального понимания языковых элементов до их чувственного восприятия» (последнее достигается через реализацию пунктов 1-5).

Таким образом, мы считаем, что активизация интереса военнослужащих к изучению языка специальности зависит от перечисленных факторов. Данные факторы учитывают значимость положительной оценочной доминанты в плане позиционирования будущей профессии. Посредством информации из разных областей гуманитарного знания происходит усиление внутренней мотивации иностранных военнослужащих, способствующей успешному формированию профессионально ориентированной коммуникативной компетенции обучающихся.

\section{Литература}

1. Аквазба Е.О., Медведев П.С. Реализация воспитательного потенциала гуманитарных дисциплин в процессе обучения студентов вуза // Общество: социология, психология, педагогика. 2016. № 10. С. 89-91. 


\section{КУЛЬТУРА. НАУКА. ОБРАЗОВАНИЕ}

2. Алексеенко О.И., Даниленко Т.В. Проблемы инновационного преподавания гуманитарных дисциплин в вузе // Современное педагогическое образование. 2019. № 5. С. 4-7.

3. Васильева Г.М., Ротмистрова О.В. Содержательные сферы культурногеографического образа России в преподавании дисциплин гуманитарного цикла // Ученые записки университета им. П.Ф. Лесгафта. 2012. № 7 (89). С. 25-29.

4. Дунаева А.С., Ветчинова М.Н. Культурологическая идея концепции коммуникативного иноязычного образования // Язык и культура. 2014. № 3 (27). С. 138-145.

5. Матисов С.К., Худолей С.С. Специфика преподавания гуманитарных дисциплин в гуманитарном вузе // Материалы 77-й международной конференции ААИ «Автомобиле- и тракторостроение в России: приоритеты развития и подготовка кадров» (27-28 марта 2012 г.). М., 2012. С. 316-318.

6. Платонова Э.Н., Садовая И.И. Особенности преподавания дисциплин социальногуманитарного цикла в системе высшей школы на современном этапе // Современные технологии обеспечения гражданской обороны и ликвидации последствий чрезвычайных ситуаций. 2013. № 1 (4). Т. 2. С. 145-148.

7. Раппопорт А.В. Преподавание гуманитарных дисциплин в технических вузах // Евразийское научное объединение. 2019. № 6-6 (52). С. 413-416.

8. Ротмистрова О.В. Условия развития самообразовательной компетенции иностранных студентов на занятиях по русскому языку // Иностранный язык и культура в контексте образования для устойчивого развития: Международный сборник научно-методических статей. Псков, 2019. Вып. 9. С. 90-97.

9. Супронова А.Н. Реализация коммуникативных технологий в обучении русскому языку иностранных военнослужащих // Педагогика. Вопросы теории и практики. Тамбов, 2019. Т. 4. Вып. 4. С. 205-210. https://doi.org/10.30853/pedagogy.2019.4.38

10. Шагбанова Ю.Б. Преподавание гуманитарных дисциплин в высшем учебном заведении: опыт и основные тенденции // Мир науки. Педагогика и психология. 2019. № 4. Т. 7. URL: https://mir-nauki.com/40PDMN419.html

Шестакова Л.А. Теоретические обоснования междисциплинарной интеграции в образовательном процессе вузов // Вестник Московского университета им. С.Ю. Витте. Серия 3: Педагогика. Психология. Образовательные ресурсы и технологии. 2013. № 1 (2). С. $47-52$.

(C) Супронова А.Н., 2020 